\title{
Toxicity of Microcystis aeruginosa peptide toxin to yearling rainbow trout (Oncorhynchus mykiss)
}

\author{
Francesca G. Tencalla*, Daniel R. Dietrich, Christian Schlatter
}

Institute of Toxicology of the Federal Institute of Technology and the University of Zürich, Schorenstr. 16, 8603 Schwerzenbach, Switzerland

\begin{abstract}
The effects of the blue-green algae (cyanobacterial) toxin microcystin-LR on yearling rainbow trout were studied in a series of intraperitoneal injection tests, gavage trials and exposures to waterborne algae. Concentrations of the microcystin-producing algae Microcystis aeruginosa known to occur during algae blooms $(8-16 \mathrm{mg}$ freeze-dried algae/L, i.e. approximately $1-2 \times 10^{11}$ cells $/ \mathrm{L}$ ) were shown to be non-toxic to trout when present in aquarium water. On the other hand, trout died within $96 \mathrm{~h}$ when gavaged with an amount of algae equivalent to that which passed through the gills within $18 \mathrm{~h}$ in the aqueous exposure tests $(1440 \mathrm{mg}$ freeze-dried algae $/ \mathrm{kg}$ body weight, i.e. $6600 \mu \mathrm{g}$ microcystin/ $\mathrm{kg}$ body weight). Oral uptake of approximately one tenth of this dose $(110 \mathrm{mg}$ freeze-dried algae $/ \mathrm{kg}$ body weight, i.e. $550 \mu \mathrm{g} \mathrm{microcystin} / \mathrm{kg}$ body weight) proved to be non-toxic in single gavaging studies, but toxic within $96 \mathrm{~h}$ when orally administered 8 times at 12 -h intervals. This study shows that the main uptake route of microcystin in trout is the gastrointestinal tract and that toxicity is manifested as massive hepatic necrosis. These results indicate that massive fish deaths reported at cyanobacterial bloom sites can be explained by the ingestion of toxic blue-green algae.
\end{abstract}

Key words: Microcystin-LR; Toxicity to trout; Uptake route; Bloom-related mortality

\section{Introduction}

In recent decades, the number of toxic blue-green algae blooms in freshwaters world-wide has increased steadily as a consequence of man-made eutrophication. One of the most common species of blue-green algae (Cyanobacteria) encountered in such blooms is Microcystis aeruginosa, a unicellular floating algae which produces a family of potent hepatotoxins called microcystins. They all possess the unique $\mathrm{C}_{20}$ amino acid ADDA - $(2 S, 3 S, 8 S, 9 S)$ - 3-amino-9-methoxy-2,6,8-trimethyl-10-phenyl-4,6decadienoic acid - and contain two sites with variable amino acid residues (Kondo et

*Corresponding author. 
al., 1992; Sivonen et al., 1992). The toxin-containing L-Leu and L-Arg is the most extensively studied and has been designated microcystin-LR. These monocyclic heptapeptides have been shown to affect not only cattle and wildlife, but also man (Carmichael and Gorham, 1981; Falconer et al., 1983; Skulberg et al., 1984; Dierstein et al., 1988).

Toxic algae blooms are often cited in conjunction with high fish mortality (Eriksson et al., 1986; Lindholm, 1991). Although it is strongly suspected that the observed mortalities are linked to the presence of toxic cyanobacteria in the water, a direct relationship between these two phenomena has never been clearly established. Earlier experiments have demonstrated that intraperitoneal (i.p.) injection of whole cells of $M$. aeruginosa strain 7820 at $1-1.5 \mathrm{mg}$ dry weight $/ \mathrm{kg}$ body weight (bw) was acutely toxic to trout within 12-24 h (Phillips et al., 1985). In carp, pure microcystinLR administered via intraperitoneal injection is acutely toxic at a dose of $550 \mu \mathrm{g} / \mathrm{kg}$ bw (Råberg et al., 1991). Generally, however, little is known about the specific toxicity of microcystin in fish. Intraperitoneal injection does not reflect the situation in the environment and fails to prove toxicity under natural conditions. The goal of this study was to clarify whether microcystin-LR is absorbed by fish, what the take-up route is (gills, skin, digestive tract), and whether it can be lethal under conditions similar to those encountered during algae blooms.

\section{Materials and methods}

Fish

Experiments were carried out on one year old rainbow trout (Oncorhynchus mykiss), mean weight 30-60 g, purchased at the Thedy Waser Commercial Fish Hatchery in Andelfingen, Switzerland. Fish were acclimated two weeks in flowthrough aquaria containing $15-18^{\circ} \mathrm{C}$ dechlorinated tap water and transferred to 100 $\mathrm{L}$ aerated recirculation tanks for the experiments. Water quality and oxygen saturation was the same in both cases. Trout were fed commercial trout food ad libitum (Hokovit No. 506, Hoffman AG, Switzerland) and feeding was interrupted $24 \mathrm{~h}$ before the beginning of each test. Prior to treatment, trout were anaesthetised by being placed in a $100 \mathrm{mg} / \mathrm{L}$ solution of Tricaine (Product No. 06955, Fluka, Switzerland).

\section{Materials}

Freeze-dried $M$. aeruginosa strain 7806 was obtained from the Swiss Federal Institute for Water Resources and Water Pollution (EAWAG). The material was analysed for toxin content as described by Meriluoto et al. (1990) and shown to contain an average of $4.6 \mu \mathrm{g}$ microcystin-LR/mg dry weight. Algae extracts were obtained by suspending $30 \mathrm{mg}$ of freeze-dried algae in $1 \mathrm{ml}$ dechlorinated water, sonicating 15 minutes and centrifuging. The procedure was repeated twice and the collective supernatants were analysed for toxin content before use. The sample was prepared for analysis as described by Dierstein et al. (1989). Pure microcystin-LR was procured from Sigma, Switzerland (Product No. M5407). 
Intraperitoneal injection experiments

In order to verify that the microcystin contained in the algae was the only factor responsible for the deaths observed, two trout were injected with either pure microcystin-LR at the concentration found to be lethal in carp (Råberg et al., 1991) or with algae extracts at the same toxin concentration (Table 1). Controls were injected with an equal volume of dechlorinated water. Upon death of the trout or termination of the experiment, tissue samples of the main organs (liver, spleen, heart, digestive tract and gills) were fixed in $4 \%$ neutral buffered formalin. Paraffin sections of $3 \mu \mathrm{m}$ thickness were stained with hematoxylin and eosin for microscopical analysis.

Table 1

Summary of the experimental conditions and main results.

\begin{tabular}{|c|c|c|c|c|c|}
\hline & $\begin{array}{l}\text { Algae } \\
\text { concentration } \\
\text { (mg/kg body } \\
\text { weight or } \mathrm{mg} / \mathrm{L} \\
\text { water) }\end{array}$ & $\begin{array}{l}\text { Microcystin-LR } \\
\text { concentration } \\
(\mu \mathrm{g} / \mathrm{kg} \text { body } \\
\text { weight or } \mu \mathrm{g} / \mathrm{L} \\
\text { water })\end{array}$ & $\begin{array}{l}\text { Lethality } \\
\text { to treated } \\
\text { fish }\end{array}$ & $\begin{array}{l}\text { Liver } \\
\text { damage }\end{array}$ & $\begin{array}{l}\text { Number of } \\
\text { fish per } \\
\text { treatment } \\
\text { group }\end{array}$ \\
\hline $\begin{array}{l}\text { Intraperitoneal } \\
\text { injection test } \\
\text { with pure } \\
\text { microcystin-LR }\end{array}$ & - & 550 & $\begin{array}{l}\text { within } \\
24 \mathrm{~h}\end{array}$ & severe & 2 \\
\hline $\begin{array}{l}\text { Intraperitoneal } \\
\text { injection test } \\
\text { with algae } \\
\text { extracts }\end{array}$ & - & 550 & $\begin{array}{l}\text { within } \\
24 \mathrm{~h}\end{array}$ & severe & 2 \\
\hline $\begin{array}{l}\text { Gavage tests } \\
\text { with } \\
\text { freeze-dried } \\
\text { algae }\end{array}$ & $\begin{array}{r}370 \\
1440\end{array}$ & $\begin{array}{l}1700 \\
6600\end{array}$ & $\begin{array}{l}\text { no } \\
\text { within } \\
96 \mathrm{~h}\end{array}$ & $\begin{array}{l}\text { none } \\
\text { severe }\end{array}$ & $\begin{array}{l}18 \\
18\end{array}$ \\
\hline $\begin{array}{l}\text { Gavage test } \\
\text { with pure } \\
\text { microcystin-LR }\end{array}$ & - & 1200 & no & none & 18 \\
\hline $\begin{array}{l}\text { Repeated } \\
\text { gavage tests } \\
\text { with freeze- } \\
\text { dried algae }\end{array}$ & 8 -times: 110 & 8 times: 550 & no & $\begin{array}{l}\text { modest- } \\
\text { severe }\end{array}$ & 5 \\
\hline $\begin{array}{l}\text { Exposure to } \\
\text { waterborne } \\
\text { freeze-dried } \\
\text { algae }\end{array}$ & $\begin{array}{r}8^{\mathrm{a}} \\
16^{\mathrm{a}}\end{array}$ & $\begin{array}{l}36.60 \\
73.10\end{array}$ & $\begin{array}{l}\text { no } \\
\text { no }\end{array}$ & $\begin{array}{l}\text { none } \\
\text { none }\end{array}$ & $\begin{array}{l}10 \\
10\end{array}$ \\
\hline
\end{tabular}

The effects on yearling rainbow trout of pure microcystin-LR or toxic freeze-dried Microcystis aeruginosa were tested in a series of intraperitoneal injection trials, gavage experiments and exposures to waterborne algae

${ }^{a}$ Corresponding cell densities: $1.33 \times 10^{11}$ and $2.66 \times 10^{11}$ cells/L, respectively. 


\section{Single gavage trials}

Groups of 18 trout were orally gavaged with approximately $1 \mathrm{ml}$ of either freezedried algae at two dose levels suspended in dechlorinated water or pure microcystinLR diluted in dechlorinated water (Table 1). The solutions were administered to fish with $9 \times 0.7 \mathrm{~cm} 1 \mathrm{ml}$ syringes (Asik, Denmark). Control fish were gavaged with plain dechlorinated water. After 3, 12, 24, 48, 72 and $96 \mathrm{~h}$, three control and three treated fish were sacrificed. Organ samples were taken for histological analysis and blood was collected for determination of plasma LDH (Lactate Dehydrogenase), ALT (Alanine Amino-Transferase) and AST (Asparagine Amino-Transferase) activities. The blood samples were obtained by heart puncture with $6 \%$ Luer $19 \mathrm{G} \times 1.5^{\prime \prime}$ needles (Terumo SA, Belgium). Anticoagulation was effected with heparin. Blood was immediately centrifuged for 10 minutes at $3000 \mathrm{~g}$ and plasma collected. LDH, AST and ALT concentrations were determined on a COBAS FARA chemistry analyser (Roche, Switzerland) with standard enzyme kits (Boehringer, Mannheim, Germany). Results were defined as mean concentration \pm standard deviation. The gavage experiments with freeze-dried algae were carried out twice.

\section{Repeated gavage trials}

The toxicity of repeated exposures to low doses of microcystin was tested by orally gavaging five trout 8 times at 12-h intervals with concentrations of freeze-dried algae shown to be non-toxic as a single dose in previous experiments (Table 1). Fish were sacrificed after $96 \mathrm{~h}$ and organ samples as well as blood were collected.

\section{Exposure to waterborne algae}

In these tests, fish were exposed to concentrations of $M$. aeruginosa in the water of 8 and $16 \mathrm{mg}$ freeze-dried algae/L, i.e. 1.33 and $2.66 \times 10^{11}$ cells/L (Table 1 ). The aerated recirculation tanks were filled with $54 \mathrm{~L}$ of water and contained ten trout per aquarium. The freeze-dried algae was added once to the test aquaria at the beginning of each experiment. The initial concentrations of cells were calculated to approximate those encountered in water and in scum $\left(\sim 10^{9}-10^{12}\right.$ cells/L) during $M$. aeruginosa blooms (Berg et al., 1987; Zohary and Madeira, 1990; Watanabe et al, 1992). The corresponding initial toxin concentrations (Table 1) were in the same range as those of oscillatoria toxin encountered during Oscillatoria agardhii blooms where fish mortality was reported (Eriksson et al., 1989; Lindholm, 1990). The comparison to Oscillatoria agardhii was chosen since corresponding data for $M$. aeruginosa blooms are lacking and the respective peptide toxins of these algae possess structural similarities and comparable hepatotoxic properties in mice (Eriksson et al., 1988). After $96 \mathrm{~h}$, control and test fish were sacrificed and liver, spleen, heart, digestive tract and gills were processed for microscopical analysis.

\section{Results}

Intraperitoneal injection of algal extracts or freeze-dried algae at a dose equivalent to $550 \mu \mathrm{g}$ microcystin $/ \mathrm{kg}$ bw resulted in $100 \%$ mortality of trout within $24 \mathrm{~h}$. In both treatments, death was due to severe necrosis of the liver. 
Single oral gavage with a 2 to 3 fold higher dose of pure microcystin-LR (1200 $\mu \mathrm{g} / \mathrm{kg}$ bw; Table 1) or freeze-dried algae ( $1700 \mu \mathrm{g}$ microcystin $/ \mathrm{kg}$ bw; Table 1) proved to have no effect on general behaviour of the trout. Histology of the organs was also not changed. The plasma enzyme concentrations in the case of the gavaging with algae cells remained constant and comparable to control values throughout the 96-h period (Fig. 1).

When fish were gavaged with freeze-dried algae at a dose corresponding to $6600 \mu \mathrm{g}$ microcystin/kg bw, an acute toxic response was observed, with $100 \%$ mortality occurring within $72 \mathrm{~h}$ the first time and $96 \mathrm{~h}$ the second time the experiment was carried out. Histological examination of the organs (liver, spleen, heart, digestive tract and gills) showed that damage was restricted to the liver and was characterised by progressive necrosis of this tissue. Damage appeared already $3 \mathrm{~h}$ after gavaging the fish with algae. At this time point, the livers appeared normal macroscopically but histological analysis demonstrated derangement of the hepatic architecture due to hepatocyte swelling. After 12 to $24 \mathrm{~h}$, trout started to show signs of lethargy, slowed reflexes, and decreased swimming activity. Livers were pale and yellowish, the hepatocytes clearly individualised and possessing pyknotic nuclei. Punctually, limited sinus congestion and microhemorrhaging into the interstitium were observed. Upon death at 72 or 96 $\mathrm{h}$, all hepatocyte membranes were undergoing lysis and the liver tissue was entirely degenerated. Damage was comparable to that observed in the i.p. injection trials after $24 \mathrm{~h}$. LDH concentrations began to rise between 3 and $12 \mathrm{~h}$ after the gavaging took place, peaked at 10-fold the control value after $24 \mathrm{~h}$ (controls: $765 \pm 97 \mathrm{U} / \mathrm{L}$ ), and then decreased. Similarly, a 15-fold increase of AST and ALT compared to controls ( $303 \pm 16$ and $11 \pm 2 \mathrm{U} / \mathrm{L}$, respectively) was detected $48 \mathrm{~h}$ after oral dosing, followed by a decline of the activity (Fig. 1).

Severe toxicity was also observed when trout were gavaged 8 times at $12-\mathrm{h}$ intervals with algae concentrations equivalent to $550 \mu \mathrm{g}$ microcystin $/ \mathrm{kg}$ bw per dosing point. Over the $96-\mathrm{h}$ period, this corresponded to a total of $4400 \mu \mathrm{g}$ microcystin $/ \mathrm{kg}$ bw. Observed symptoms were similar to those described for the single uptake of algae at $6600 \mu \mathrm{g}$ microcystin/kg bw. In this case however, no mortality occurred within $96 \mathrm{~h}$ although trout became severely lethargic as soon as $48 \mathrm{~h}$ after treatment began. With multiple gavage, the progression of damage was slower. After $96 \mathrm{~h}$, an inflammatory response could be observed in the liver tissue, with striking zonal infiltration of leukocytes and focal necrosis. At this time point, ALT was elevated, reaching twice the control values $(19 \pm 3 \mathrm{U} / \mathrm{L}$ for treated animals; $10 \pm 1 \mathrm{U} / \mathrm{L}$ for controls). $\mathrm{LDH}$ and AST values were not significantly'different from those of control fish (1138 \pm 345 and $266 \pm 109 \mathrm{U} / \mathrm{L}$, respectively, for treated animals; $1018 \pm 149$ and $176 \pm 62 \mathrm{U} / \mathrm{L}$ for controls).

When exposed to algae in the water, trout sustained no mortality and showed no significant clinical or histological changes over a 96-h period at either of the doses tested. Based on a trout ventilation rate of $0.175 \mathrm{~L} / \mathrm{kg} \mathrm{bw} / \mathrm{min}$ (Addison, 1982), each fish in the treated group would have been exposed to approximately 1440 and 2880 $\mathrm{mg}$ algae/ $\mathrm{kg}$ bw, respectively, within an $18 \mathrm{~h}$ time frame. This would correspond to one and two-fold the algae concentration found to be acutely toxic within $96 \mathrm{~h}$ when applied to fish as a single dose via oral gavaging (Table 1). 

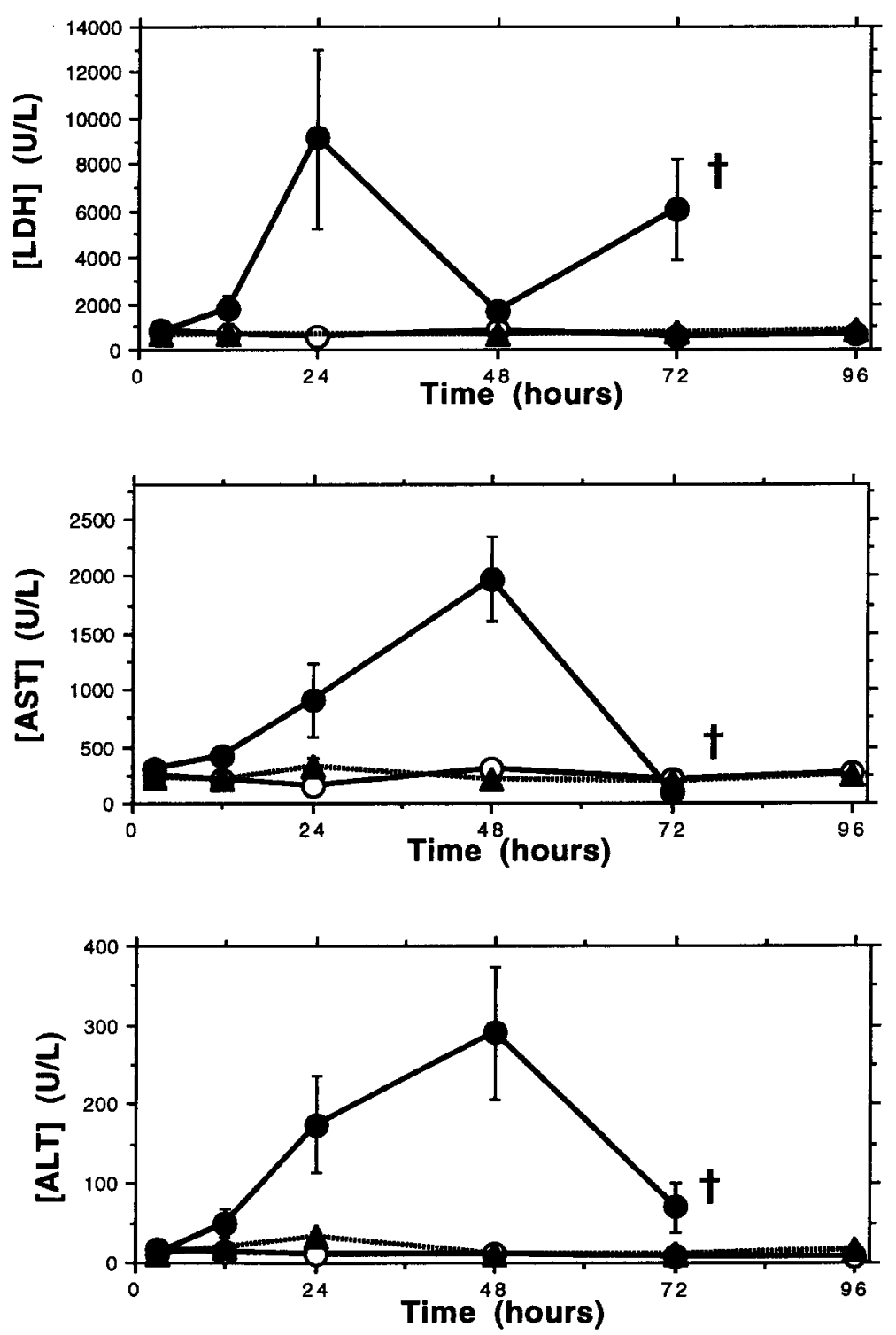

Fig. 1. Change of LDH, AST and ALT concentrations in trout plasma during the $96 \mathrm{~h}$ gavaging experiments. Each point represents the mean value obtained from three animals. $O$, controls; $\Delta$, trout gavaged with $1700 \mu \mathrm{g}$ microcystin/kg bw in the form of freeze-dried algae; $\bullet$, trout gavaged with $6600 \mu \mathrm{g}$ microcystin $/ \mathrm{kg}$ bw in the form of freeze-dried algae.

\section{Discussion}

It is shown in the present study that comparable concentrations of microcystinproducing blue-green algae were acutely toxic when gavaging was carried out to 
simulate feeding but had no effect on trout when present in the aquarium water. These results demonstrate that $M$. aeruginosa can be directly toxic to fish. This is in contradiction to the conclusions of Phillips et al. (1985) according to whom during bloom situations hepatotoxins from this alga are unable to gain entry into the organism of rainbow trout in sufficient amounts to cause death. The experiments further indicate that the route of uptake of the toxin is the gastro-intestinal tract and that only negligible amounts enter the system via the gills or the skin. Microcystin proved to be acutely toxic via intraperitoneal injection at a dose approximately 10 times lower than those causing effects in the single and repeated gavage experiments. This observations indicates that absorption of the toxin is only about $10 \%$, thus corresponding to the general behaviour of peptides which are partially digested before reaching the gastrointestinal epithelium and do not easily permeate through cell membranes.

In the i.p. as well as the gavage trials, the toxic manifestations of microcystin in trout were restricted to the liver and were characterised by hepatocyte rounding, derangement of hepatic architecture and progressive necrosis of the tissue. The changes in the activities of the plasma enzymes proved to be a good reflection of the microcystin-induced damage in the liver. In the first $3 \mathrm{~h}$ after gavaging with high doses of algae, hepatocytes were deformed but their cellular membranes remained intact. During this period, LDH, AST and ALT values were not significantly different in test and control groups. Since these enzymes are essentially restricted to the cytoplasm, their concentrations in the blood are not expected to increase until cell membranes lyse. After $3 \mathrm{~h}$, progressive cell necrosis appeared and enzyme concentrations began to rise. Their consecutive decrease could be explained by the fact that after 48-72 h, all cells appeared ruptured and no further enzymes would have been released into the bloodstream.

The symptoms and enzyme values observed in trout are comparable to those described in carp following i.p. injection. In the present experiments however, no damage was observed in the kidneys even at high toxin concentrations. In carp, degenerative changes in tubuli, glomeruli, and interstitial tissue have been described (Råberg et al., 1991). Microcystin therefore appears to act similarly on different types of fish but species-specific differences in sensitivity and secondary target organs exist.

A striking similarity can also be observed when comparing fish and mammals. It is interesting to note that although numerous differences exist between homeotherms and poikilotherms with respect to morphology, physiology and biochemistry of the organs, the lethal concentrations of pure toxin administered via i.p. injection, as shown in Table 2, are within the same range. In mammals, it has been shown that MC accumulates essentially in the liver (Runnegar et al., 1986; Eriksson et al.,1990a); Robinson et al., 1991) where it binds to protein phosphatases type 1 and 2A (Eriksson et al., 1990b); Honkamen et al., 1990; MacKintosh et al., 1990; Yoshizawa et al., 1990) and provokes hepatocyte deformation, liver necrosis (Meriluoto et al., 1989) and elevation of plasma enzyme values (Miura et al., 1989; Jackson et al., 1984; Galey et al., 1987). Transport to the liver occurs via the carrier system for bile acids (Runnegar et al., 1981). The fact that, in trout, microcystin is toxic when taken up orally and is a specific hepatotoxin may suggest that this toxin is also taken up by fish via the bile acid transport system. Furthermore, the effects of microcystin in the liver are compa- 
Table 2

Toxicity of intraperitoneal injection of pure microcystin-LR in different species of mammals and fish

\begin{tabular}{lc}
\hline Species & $\begin{array}{l}\text { Lethal dose } \\
(\mu \mathrm{g} / \mathrm{kg} \text { body weight })\end{array}$ \\
\hline mouse & $50-250^{\mathrm{a} . \mathrm{b}}$ \\
rat & $100^{\mathrm{c}}$ \\
carp & $550^{\mathrm{d}}$ \\
trout & $550^{\mathrm{e}}$ \\
\hline
\end{tabular}

References: a Carmicheal, $1992 ;{ }^{\mathrm{b}} \mathrm{R}$ unnegar et al, $1987 ;{ }^{\mathrm{C}} \mathrm{Muira}$ et al, $1989 ;{ }^{\mathrm{d}} \mathrm{R}$ åberg et al, $1991 ;{ }^{\mathrm{e}}$ data presented in this paper.

rable in trout and in mammals and it appears that a certain accumulation of the toxin in the liver of fish is possible, as suggested by the repetitive gavage experiments. The possibility therefore exists that microcystin acts also in fish via the same route as in mammals, i.e. by binding to protein phosphatases. In contrast to the situation in mammals however, trout and carp exposed to microcystin did not present with massive hepatic hemocongestion or hemorrhage, whereas this is a prominent feature in the livers of microcystin intoxicated mammals (Carmichael, 1992). This observation suggests that in the case of fish, hepatic damage consists mainly of severe necrosis of hepatocytes rather than massive intrahepatic hemorrhage.

The likelihood of microcystin toxicity to fish in the natural environment can be estimated with the following rough calculation. Under the present test conditions, a $60 \mathrm{~g}$ trout orally dosed with approximately $80 \mathrm{mg}$ of freeze-dried algae $(6600 \mu \mathrm{g}$ microcystin $/ \mathrm{kg} \mathrm{bw}$ ) died within $96 \mathrm{~h}$ from acute liver damage. In the natural environment, a $60 \mathrm{~g}$ strictly algae-feeding fish would consume approximately $10 \%$ of its body weight per day, that is $6 \mathrm{~g}$ of wet material, i.e. $120-300 \mathrm{mg}$ of dry material each day, based on the fact that algae contain approximately $95-98 \%$ water. This is the equivalent of $9000-23000 \mu \mathrm{g}$ microcystin $/ \mathrm{kg}$ bw/day, i.e. approximately $1.5-3.5$ times the single dose found to be lethal in the laboratory experiments presented here. Under the assumption that fish actually feed on blue-green algae when present, microcystin intoxication of algae-feeding species is therefore highly likely during cyanobacterial blooms. In the environment, however, mortality during toxic algae blooms also involves mixed-diet fish (Lindholm, personal communication, 1991), raising the question whether exposure to lower doses of toxin over prolonged periods of time can also be lethal. The repeated gavage study showed that $550 \mu \mathrm{g}$ microcystin $/ \mathrm{kg}$ bw taken up twice a day for 4.5 days caused massive liver damage. For a $60 \mathrm{~g}$ trout, this is equivalent to ingesting as little as $0.1-0.4 \mathrm{~g}$ of algae wet weight or $0.2-0.6 \%$ of its body weight twice daily during the time of a short algae bloom. Mixed-diet fish, like strict algae feeders, therefore also appear to be prone to blue-green algae intoxication during toxic algae blooms.

The observations reported in this paper demonstrate the oral toxicity of microcystin to trout at concentrations well below those which are encountered during toxic blue-green algae blooms. These data indicate that fish mortality reported at algal bloom sites is due to the ingestion of cyanobacterial toxins. 


\section{Acknowledgement}

We thank M. Lukàc from the Swiss Federal Institute for Water Research and Water Pollution Control (EAWAG) for providing us with the algal material, B. Car for his comments on the manuscript and R. Candrian for technical assistance.

This study was supported by a grant from the Swiss Environmental Protection Agency (BUWAL) and the Swiss National Science Foundation (Grant No. 3133344.92).

\section{References}

Addison, R.F. (1982) Organochlorine compounds and marine lipids. Prog. Lipid Res. 21, 47.

Berg, K., W.W. Carmichael, O.M. Skulberg, C. Benestad, B. Underdal (1987) Investigation of a toxic water-bloom of Microcystis aeruginosa (Cyanophyceae) in lake Akersvatn, Norway. Hydrobiologia 144, 97-103.

Carmichael, W.W. (1992) Cyanobacteria secondary metabolites - the cyanotoxins. J. Appl. Bacteriol. 72, 445-459.

Carmichael, W.W. and P.R. Gorham (1981) The mosaic nature of toxic blooms of cyanobacteria. In: The Water Environment: Algal Toxins and Health, edited by Wayne W. Carmichael. Plenum Press, New York/London, pp. 161-172.

Dierstein, R., I. Kaiser, J. Weckesser (1988) Rapid determination of Microcystis sp. toxins by reversedphase liquid chromatography. FEMS Microbiol. Lett. 49, 143-147.

Eriksson, J.E., J.A.O. Meriluoto, T. Lindholm (1986) Can cyanobacterial peptide toxins accumulate in aquatic food chains? In: Proc. IV ISME, pp. 655-658.

Eriksson, J.E., J.A.O. Meriluoto, H.P. Kujari, O.M. Skulberg, (1988) A comparison of toxins isolated from the cyanobacteria Oscillatoria agardhii and Microcystis aeruginosa. Comp. Biochem. Physiol. C 89, $207-210$.

Eriksson, J.E., J.A.O. Meriluoto, T. Lindholm (1989) Accumulation of peptide toxin from the cyanobacteria Oscillatoria agardhii in the freshwater mussel Anodonta cygnea. Hydrobiologia 183, 211-216.

Eriksson, J.E., L. Grönberg, S. Nygård, J.P. Slotte, J.A.O. Meriluoto (1990a) Hepatocellular uptake of ${ }^{3} \mathrm{H}$-dihydromicrocystin-LR, a cyclic peptide toxin. Biochem. Biophys. Acta 1025, 60-66.

Eriksson, J.E., D. Toivola, J.A.O. Meriluoto, H. Karaki, Y-G. Han, D. Hartshorne (1990b) Hepatocyte deformation induced by cyanobacterial toxins reflects inhibition of protein phosphatases. Biochem. Biophys. Res. Commun. 173, 1347-1353.

Falconer, I.R., A.M. Beresford, M.T. Runnegar (1983) Evidence of liver damage by toxin from a bloom of the blue-green alga, Mierocystis aeruginosa. Med. J. Aust. I(11), 511-514.

Galey, F.D., V.R. Beasley, W.W. Carmichael, G. Kleppe, S.B. Hooser, W.M. Haschek (1987) Blue-green algae (Microcystis aeruginosa) hepatotoxicosis in dairy cows. Am. J. Vet. Res. 48, 1415-1420.

Honkamen, R.E., J. Zwiller, R.E. Moore, S.L. Daily, B.S. Khatra, M. Dukelow, A.L. Boynton (1990) Characterisation of microcystin-LR, a potent inhibitor of type 1 and type $2 \mathrm{~A}$ protein phosphatases. J. Biol. Chem. 265(32), 19401-19404.

Jackson, A.R., A. McInnes, I.R. Falconer, M.T. Runnegar (1984) Clinical and pathological changes in sheep experimentally poisoned by the blue-green alga Microcystis aeruginosa. Vet. Pathol. 21, $102-113$.

Kondo, F., Y. Ikai, H. Oka, N. Ishikawa, M.F. Watanabe, M. Watanabe, K. Harada, M. Suzuki (1992) Separation and identification of microcystins in cyanobacteria by frit-fast atom bombardment liquid chromatography/mass spectrometry. Toxicon 30, 227-237.

Lindholm, T. (1991) Toxic cyanobacteria in finnish lakes. Rep. Suwa Hydrobiol. 7, 65-72.

Lindholm, T. and J.E. Eriksson (1990) Limnological changes in two recently isolated lakes. Limnologica 20, 273-278.

MacKintosh, C., K.A. Beattie, S. Klumpp, P. Cohen, G.A. Codd, (1990) Cyanobacterial microcystin-LR is a potent and specific inhibitor of protein phosphatases 1 and $2 \mathrm{~A}$ from both mammals and higher plants. FEBS 264, 187-192. 
Meriluoto, J.A.O., A. Sandstrom, J.E. Eriksson, G. Remaud, A.G. Craig, J. Chattopadhyaya (1989) Structure and toxicity of a peptide hepatotoxin from the cyanobacterium Oscillatoria agardhii. Toxicon 27, 1021-1934.

Meriluoto, J.A.O., J.E. Eriksson, K. Harada, A.M. Dahlem, K. Sivonen, W.W. Carmichael (1990) Internal surface reversed-phase high-performance liquid chromatographic separation of the cyanobacterial peptide toxins microcystin-LA, -LR, -YR, -RR and nodularin. J. Chromatogr. 509, 390-395.

Miura, G.A., N.A. Robinson, T.W. Geisbert, K.A. Bostian, J.D. White, J.G. Pace (1989) Comparison of in vivo and in vitro toxic effects of microcystin-LR in fasted rats. Toxicon 27, 1229-1240.

Park, H-D., M.F. Watanabe, K-I. Harada, H. Nagai, M. Suzuki, M. Watanabe, H. Hayashi (1993) Hepatotoxin (microcystin) and neurotoxin (anatoxin-a) contained in natural blooms and strains of cyanobacteria from Japanese freshwaters. Natural Toxins 1, 353-360.

Phillips, M.I., R.J. Roberts, J.A. Stewart, G.A. Codd (1985) The toxicity of the cyanobacterium Microcystis aeruginosa to rainbow trout, Salmo gardnieri Richardson. J. Fish Dis. 8, 339-344.

Råberg, C.M.I., G. Bylund, J.E. Eriksson (1991) Histopathological effects of microcystin-LR, a cyclic peptide toxin from the cyanobacterium (blue-green alga) Microcystis aeruginosa, on common carp (Cyprinus carpio L.). Aquat. Toxicol. 20,131-146.

Robinson, N.A., J.G. Pace, C.F. Matson, G.A. Miura, W.B. Lawrence (1991) Tissue distribution, excretion and hepatic biotransformation of microcystin-LR in mice. J. Pharmacol. Exp. Therapeutics 256(1), 176-182.

Runnegar, M.T., I.R.Falconer, J. Silver (1981) Deformation of isolated rat hepatocytes by a peptide from the blue-green alga Microcystis aeruginosa. Naunyn-Schmiedeberg's Arch. Pharmacol. 317, 268-272.

Runnegar, M.T., I.R. Falconer, T. Buckley, A.R.B. Jackson (1986) Lethal potency and tissue distribution of ${ }^{125}$ I-labelled toxic peptides from the blue-green alga Microcystis aeruginosa. Toxicon 24, 506-509.

Runnegar, M.T., J. Andrews, R.G. Gerdes, I.R. Falconer (1987) Injury to hepatocytes induced by a peptide toxin from the cyanobacterium Microcystis aeruginosa. Toxicon 25, 1235-1239.

Sivonen, K., M. Namikoshi, W.R. Evans, W.W. Carmichael, F. Sun, L. Rouhiainen, R. Luukkainen, K.L. Rinehart (1992) Isolation and characterization of a variety of microcystins from seven strains of the cyanobacterial genus Anabaena. Appl. Environ. Microbiol. 58, 2495-2500.

Skulberg, O.M., G.A. Codd, W.W. Carmichael (1984) Toxic blue-green algal blooms in Europe: a growing problem. Ambio 13, $244-247$.

Watanabe, M.F., K. Tsuji, V. Watanabe, K-I. Harada, M. Suzuki, (1992) Release of heptapeptide toxin (microcystin) during the decomposition process of Microcystis aeruginosa. Natural Toxins 1, 48-53.

Wicks, R.J. and P.G. Thiel (1990) Environmental factors affecting the production of peptide toxins in floating scums of the cyanobacterium Microcystis aeruginosa in a hypertrophic african reservoir. Environ. Sci. Technol. 24, 1413-1418.

Yoshizawa, S., R. Matsushima, M.F. Watanabe, K-I. Harada, A. Ichihara, W.W. Carmichael, H. Fujiki (1990) Inhibition of protein phosphatases by microcystin and nodularin associated with hepatotoxicity. J. Cancer Res. Clin. Oncol. 116, 609-614.

Zohary, T. and A.M.P. Madeira (1990) Structural, physical and chemical characteristics of Microcystis aeruginosa hyperscums from a hypertrophic lake. Freshwater Biol. 23, 339-352. 